\title{
DDD-E model: Teaching four arithmetic operations in decimal expressions using the problem-based learning approach
}

\author{
Şeyma ATAHAN a * (D), Sevinç MERT UYANGÖR a (D) \\ a Balikesir University, Turkey
}

Suggested citation: Atahan, Ş. \& Mert Uyangör, S. (2021) DDD-E Model: DDD-E model: Teaching four arithmetic operations in decimal expressions using the problem-based learning approach. Journal of Educational Technology \& Online Learning, 4(4), 759-773.

\begin{tabular}{ll}
\hline Article Info & Abstract \\
\cline { 2 - 4 } $\begin{array}{l}\text { Keywords: } \\
\text { DDD-E model } \\
\text { Problem-Based Learning }\end{array}$ & $\begin{array}{l}\text { In this study, it is aimed to reveal students' attitudes and views on a micro-lesson design } \\
\text { application in accordance with the DDD-E model in which the Problem Based Learning } \\
\text { (PBL) approach is integrated. In the study, a micro-level instructional design that } \\
\text { addressed the outcomes of the subject "Four Arithmetic Operations in Decimals" } \\
\text { contained within the scope of a 6th grade math curriculum was planned. A blended } \\
\text { pattern approach was employed in the study which aimed to integrate the PBL stages } \\
\text { with the steps of the DDD-E model. Quantitative data was collected by use of an } \\
\text { "achievement test" and a "Technological Attitude Scale for Students" prepared by an } \\
\text { instructor. Qualitative data was obtained through open-ended questions involved in a } \\
\text { feedback form on the use of technology in learning. Analyses were conducted by two } \\
\text { mathematics education expert. In the quantitative data analysis, the level of coherence } \\
\text { between encoders was } 83 \% \text {. Ultimately, affirmative changes were observed in the } \\
\text { opinions of the students on the use of technology in learning with the help of the micro- } \\
\text { level instructional design in question. Furthermore, an increase was detected in the grade } \\
\text { average of the scale. The process of making their own decisions for the students in the } \\
\text { DDD-E design model contributed to the creativity of the students and enabled them to } \\
\text { learn about a plurality of multimedia tools. Additionally, with the help of the PBL } \\
\text { approach, the students were able to produce creative and unique solutions for the problem } \\
\text { cases they encountered and were able to experience possible cases they might face } \\
\text { mathematically in real life. }\end{array}$ \\
\hline Research Article
\end{tabular}

\section{Introduction}

Today, the last point that countries have reached in terms of technology is now at an irreversible stage (Daghan, Kalayc1 \& Seferoglu, 2011). Especially after 1980, rapid developments in information technologies (IT) have significantly affected all systems of today's societies. One of the systems affected by these developments is undoubtedly the education system (Goktas, Y1ldırım \& Y1ldirım, 2008). In the twenty-first century, learning has focused on the processes in which students apply the materials they learn, use meaningful technology, and collaborate effectively (Nugraha, 2017). With the advent of technology,

\footnotetext{
* Corresponding author: Balıkesir University,Instıtute of Science, Balıkesir,Turkey.

e-mail address: seymaatahan@gmail.com

This study was partly presented as a proceeding at the 1st International Conference on Educational Technology and Online Learning Conference held between 22-24 September 2021.
} 
all of the events occurring across the world can be learned by many people in a short time by means of television and internet. Technological development not only enables face-to-face communication but also virtual and distance communication. Thus, learning can now take place not only by means of direct (faceto-face) communication but also via multimedia (indirect) communication. Multimedia is a combination of texts, arts, sounds, animations and videos through computers or electronical and digital equipment (Kaya, 2002).

Use of multimedia tools such as pictures and animations provided with sounds, videos, and information in text form can enable individuals in need to gain an accurate meaning of the information being presented. Trends in instructional research have shown that problem-based approaches help students acquire more long-lasting learning (Anazifa \& Djukri, 2017). However, the use of problem cases in learning is not widespread due to insufficient insight for the use of problem cases in several types of contexts, and doubts on integrating problem-based studies into learning programs and their use in different learning contexts (Delisle, 1997). Mathematics is a subject that requires the application of construction-based learning as students not only read and understand concepts but also directly partake in the process of understanding their meanings. Therefore, innovation is required in this context. Problem-based applications are a preferable alternative for creating an interactive and entertaining learning process (Kılıç and Moralar, 2015). As such, technological development can be used as an instrument to support learning activities. Through the use of problem-based learning, students can become more motivated and be encouraged to discover mathematic concepts in a clear and concise manner (Uygun \& Işık Tertemiz, 2014; Kılıç \& Moralar, 2015; Anazifa \& Djukri, 2017; Divarc1 \& Saltan, 2017; Alıc1, 2018; Tutak, 2021). In this sense, when the contents of EIN (educational informatics networks) were examined, it was seen that video-based lessons, multiple-choice tests, and occur.

\subsection{What is Problem-Based Learning?}

Problem-Based Learning (PBL) is a learning method that prioritizes students, is based on active learning, contributes to the ability of students to solve problems as well as their academic development, and is aimed at understanding and creating solutions to problem cases related to cases understood (Bağc1, 2003). The foundation of PBL is comprised of "scenarios" called "fictionalized cases" in which problem cases related to real life are presented. Such scenarios aim to guide and direct in line with predetermined targets throughout the learning process. With the provided scenarios, students encounter a variety of problems and produce a variety of creative solutions to solve these problems. In addition, they take an active role in this process with high internal motivation. Within the scope of PBL, students use previous experiences and previously learned information to create possible answers for solving the problems presented in each scenario in light of newly attained information (Ersoy and Başer, 2011).

PBL is a process in which studies following a learning cycle model for understanding or resolving a problem are carried out. PBL is well suited for technology intagrated instructional design such as DDD-E model. With this model it helps students develop skills and confidence to solve real-life problems with some technological material, media, web 2.0 tools etc. during the education term (Bransford, Vye \& Bateman, 2002).

It is not possible to talk about a series of fixed and definite steps in the PBL application process. Therefore, researchers have proposed different steps to reflect the characteristic structure of the PBL process (Stepien, Gallagher \& Workman, 1993; Hmelo-Silver, 2004; Hung, 2009). In the study, by drawing on the existing literature, a PBL process integrated with DDD-E Model was operated by following the five stages explained below (Alıc1, 2018):

1) Definition of the Problem: A real life problem or a direct engineering problem is presented. What is known about the problem and what is required is listed through brainstorming in line with the mutual exchange of ideas and interaction among students. 
At this stage, students correlate their previous information or experiences with the subject.

2) Gathering Necessary Information: This stage includes researching what is required to learn to solve the problem and gathering information sources.

3) Research Stage: In this stage, students take responsibility of their own learning processes and initiate creation of offer solutions to the problem. This stage includes the active processes of creating a hypothesis to solve the problem, building an experimental plan to evaluate the hypothesis, and applying this plan.

4) Transferring and Designing: In this stage, in line with the data obtained in the previous stage, ideas are suggested for solving the problem by means of brainstorming, a design is created, and this created design is assessed.

5) Communication: This stage includes creating new ideas to enhance the design and improving the design in line with these ideas, and also re-testing practices.

When the literature related to PBL is examined, the work of Cantürk-Günhan and Başer (2009 demonstrated that the PBL method has more favorable effects on student critical thinking skills within the scope of mathematics compared to conventional instructional methods. Uygun and Tertemiz (2014) determined that a positive improvement was seen in the academic success and the level of permanence thereof in primary school students who used PBL. Divarc1 and Saltan (2017) established that PBL was more efficient in improving academic success compared to the current approach employed in the learning program. Eroğlu, Aydoğdu and Tutak (2020) showed that students who used PBL were more successful in mathematics, and also had a more positive attitude to the course. Anazifa and Djukri (2017) pointed out that problem-based learning had a positive effect on the creativity and critical thinking skills of students. Finally, Nurtanto, Fawaid and Sofyan (2019) suggested that more PBL-based activities were necessary in PBL classes in order to enhance students' mathematical literacy and creative thinking skills for mathematical problems.

After considering these studies, the present study aimed to create a micro-level instructional design in which the Problem-Based Learning approach was utilized. Such instructional design is related to the use, arrangement and, if necessary, rearrangement of instructional components and mental activities to provide the maximum efficiency in all kinds of instructional activities in terms of both materials, students, teachers, and also society with the aim of enhancing outcomes (İpek \& Sözcü \& Rushan, 2013). In light of present technological developments, it is seen that innovation in the instructional systems used in education and the use of various instructional approaches and models (web-based learning, online learning, e-learning, etc.) have become more preferable due to concepts such as the universalization of information, learning independent of material facts, (classroom environment, face-to-face communication, etc.), cost, and the need for life-long learning (Usluel and Mazman, 2009).

When the stages of PBL were considered in line with the present technological development, the necessities of the time, and the need for innovation, it was seen that the integration of the stages of the DDD-E model, which is an e-learning design, with the aforementioned stages was appropriate and, in this sense, the DDDE model was addressed in the study.

\subsection{The DDD-E Learning Model}

Thanks to the considerable advances of technology since the 21 st century, novel instructional design models have emerged with the development of multiple learning (multimedia learning) and online learning systems for e-learning. One of these is the DDD-E model, which is a design model for e-learning projects within the e-learning process. The DDD-E model, pictured in Figure 1, consists of 4 stages which are Decide, Design, Develop, and Evaluate (Ivers and Barron, 2010). 


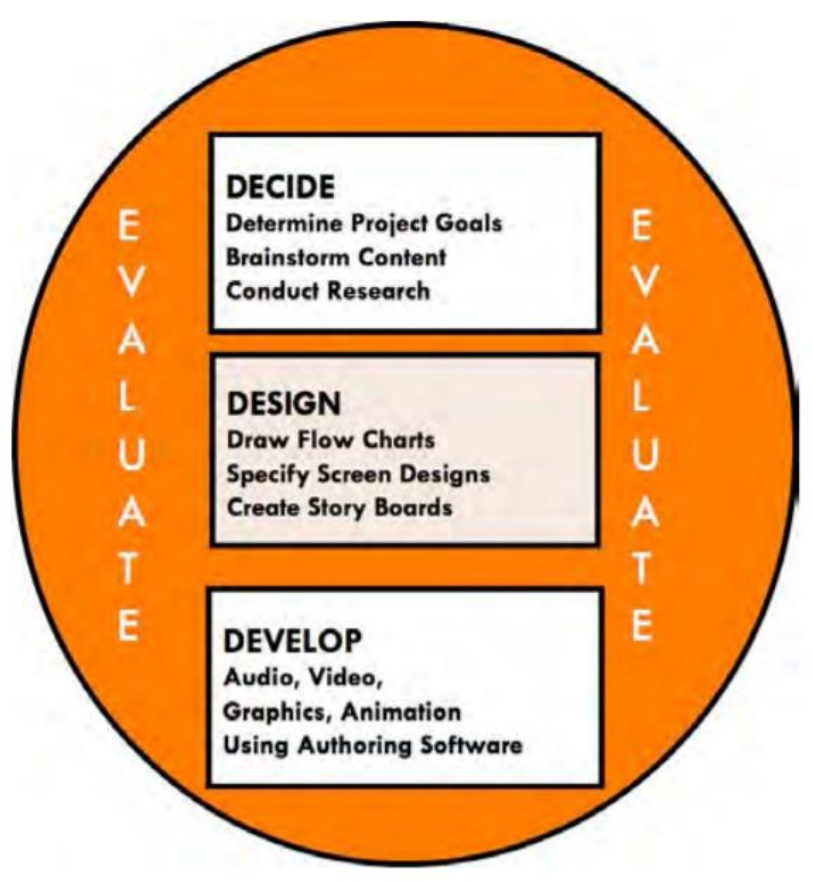

Fig. 1. DDD-E Model (Ivers \& Barron,2010)

Within this model, the activities for project planning that are used in an instructional design for students, and the extent of teacher participation in this process are as follows:

- D-decide: This stage covers instructional targets, instructional standards, brainstorming activities, and the formation of collaborative learning groups. Instructors are more active during the educational process (Ivers \& Barron, 2010). In this stage, researchers analyze and determine a number of criteria including the types of software and hardware to be used for suitably functionalizing the learning environment as well as activities and students' ability to use the hardware in order to develop game-based multimedia (Wahidah et all, 2020).

- D-design: In this stage, the process is evaluated in an attempt to determine the design plan and shortcomings of a project in planning and implementing the project to be created. Students determine the content they wish to use and create flow charts, arrangements thereof, and Story Boards for software (Ivers \& Barron, 2010). At this stage, researchers conduct a material analysis to determine the depth and extent of the material. After the process of material analysis is completed, a flow chart and storyboard are created (Ellis-Barrett, 2007). Flow charts are created to provide an overall view for the flow or course of an interactive learning environment from one scene to another. A storyboard or visual instruction file is created to define every scene including visual appearance, sound, time, and other related information (Wahidah et all, 2020).

- D-develop: In this stage, media materials are created and gathered to make the process of learning more effective and simpler. Instructors assume the role of guide rather than teacher, manage media production and multiple learning activities, and address any shortcomings they notice. Students develop materials such as graphics, animations, auditory and visual videos through the use of the multimedia tools provided by their instructors (Ivers \& Barron, 2010). At this stage, researchers develop interactive elements of the learning environment in which materials such as written texts, illustrations, animations, and sounds are required. Then, researchers create interactive learning mediums by using the software determined in the Decide stage (Wahidah et all, 2020). 
- E-evaluate: Evaluation is applicable to each of the previously mentioned stages. In this stage, instructors are responsible to evaluate their students and revising their activities to improve them for prospective applications. Students correct shortcomings and mistakes related to the project outcomes created in multiple mediums, evaluate their intra-group work, and conduct selfevaluations. Evaluation is not only one stage of the DDD-E model but also a process that is actively performed at every stage in the model (Ivers \& Barron, 2010). In this stage, the researcher evaluates interactive learning media outcomes. In this study, the process of evaluation includes formative evaluation by using materials, media, language, and student skills (Ellis-Barrett, 2007). This stage is completed with a one-to-one evaluation by a specialist and an evaluation of the students, which is followed by a small group evaluation and then a test evaluation. In this context, the conceptual process of the DDD-E Model is given in Figure 2 (Wahidah et all, 2020).

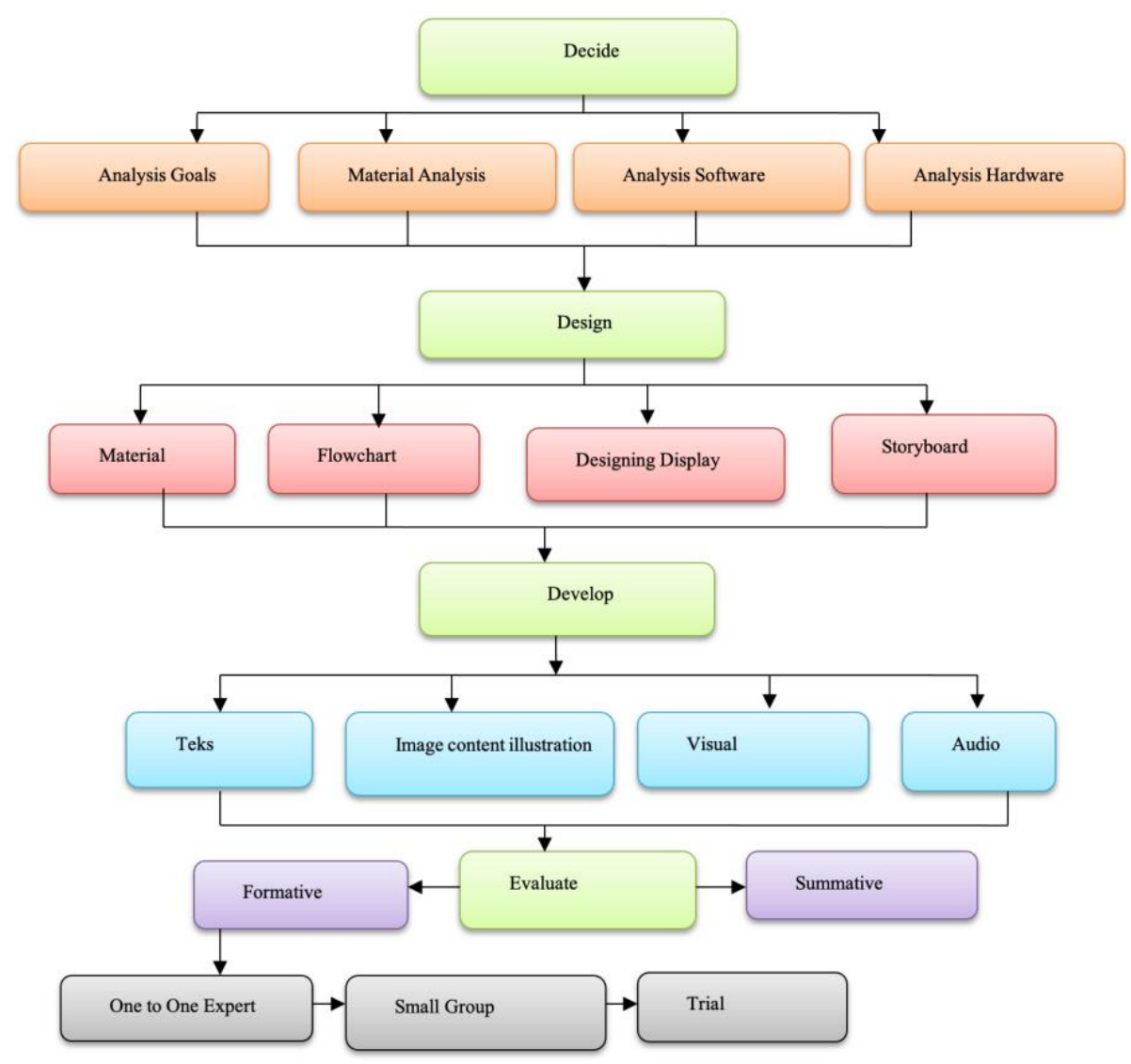

Fig. 2. Conceptual process of the DDD-E Model

Multimedia is the combination of text, art, sounds, animations, and videos that are transferred by means of computers or electronic and digital equipment. A literature review related to the DDD-E e-learning design showed only a limited number of studies (Ivers \& Barron, 2002; Ellis-Barrett, 2007; Ivers \& Barron, 2010; Wahidah et all, 2020). The use of the DDD-E model in this study aims to contribute to this deficiency in the literature.

\subsection{Research Problem}

In line with the aim of the research, the question "What are the opinions and attitudes of $6^{\text {th }}$ grade students regarding the subject 'Four Arithmetic Operations in Decimals' taught with the Problem-Based Learning Approach adapted to the DDD-E Model?" was asked and the sub-problems are given below: 
Sub-problem 1: "What are the opinions of the students regarding the subject 'Four Arithmetic Operations in Decimals' taught with the Problem-Based Learning Approach adapted to the DDD-E Model?"

Sub-problem 2: "What is the attitude level of the students regarding the subject 'Four Arithmetic Operations in Decimals' taught with the Problem-Based Learning Approach adapted to the DDD-E Model?"

\section{Methodology}

\subsection{Research Model/Design}

In the study, a micro-level instructional design that addresses the outcomes of the subject "Four Arithmetic Operations in Decimals" contained within the scope of a $6^{\text {th }}$ grade math curriculum was planned. The study aimed to integrate the stages of PBL with the steps of the DDD-E model and was conducted using a case study, which is one of the qualitative research methodology patterns. According to Stake (2005), case studies are divided in 3 groups: real, instrumental, and collective case studies. In the present research, a real case study was preferred and was thus conducted in order to better understand the current state. Twenty 6 th grade students at a private school in the city of Balıkesir were selected for the research by means of a simple available case sample, and they formed the study group of the research.

\subsection{Data Collecting Tools}

Quantitative data of the study were gathered with an "Achievement Test for Four Arithmetic Operations in Decimals"(Appendix-1) prepared by the instructor and an "Attitude Scale for Students to Technology" prepared by Yurdugül and Aşkar (2008). This scale employs 24 items in total: 15 positive and 9 negative items. Qualitative data were gathered by means of a semi-structured feedback form that was prepared by the researchers.

\subsection{Sampling or Study Group}

The study group consisted of $206^{\text {th }}$ grade students studying in a private school in Balikesir, by using purposive sampling method. The reason for this is that due to the pandemic conditions at the time of the research, the research could only be conducted with students who had remote access, technological facilities and online communication.

\subsection{Data Analysis}

Data were analyzed using the SPSS 22.0 package program. In the research, descriptive data statistics were employed in the analysis of the data pertaining to the participants. For Achievement Test for Four Arithmetic Operations in Decimals, a draft of 30 questions in total, which was prepared during the development of the achievement test, was prepared and sent to the experts. Afterwards, an achievement test with a total of 12 questions was created in line with the expert opinion. The questions in each part are openended and selected to measure four operations skills in decimal numbers. The achievement test was composed of 12 questions, each of which corresponds to 5 points, and was assessed out of 60 points in total. In the findings obtained from the Attitude Scale for Students to Technology, negative items were inversely encoded and analyzed depending on an average point. To determine an accurate decision on the opinions of the participants regarding the subject, their arithmetic mean points were calculated. Regarding this, a graduation scale for arithmetic mean points is as the following (Cerit, 2008):
$1.00-1.80$ Strongly Disagree
$1.81-2.60$ Disagree
$2.61-3.40$ Neutral
$3.41-4.20$ Agree
4.21 - 5.00 Strongly Agree

The findings obtained from the "Feedback Form for the Use of Technology in Education" were analyzed using content analysis. The interview form was validated by utilizing expert opinion. The interview form 
was administered to each student in the study group and was comprised of two questions: "What are your opinions on activities in which technology and mathematics are involved together?" and "What do you think about solving daily life problems encountered in mathematics by using technology? Please explain in detail." Within the framework of these questions, twenty interview forms were assessed. A process of encoding was performed depending on the results pertaining to the explanations and expressions of the students on the blending of problem-based learning with technology in line with the DDD-E model. Afterwards, a process of thematization was conducted in line with the encoding performed, and then the frequency values of the themes were calculated, listed in a table, and interpreted. The process that was performed within the scope of the content analysis was based on gathering analogous data under certain themes by means of encoding and on arranging and interpreting them in such a manner that readers are able to understand (Karataş, 2017).

\subsection{Validity and Reliability of the study}

Yin (1984)'s recommendations were used for the validity and reliability of this study. In order to increase the construct validity of the study, more than one data collection tool was used in the data collection process and each step of the study was well defined. For reliability, the researchers developed the study step by step within a certain system and each step was explained in detail and supported with documents.

Triangulation is the comparison of the results of two or more data collection methods (for example, interviews and observations) or two or more data sources (for example, individual interviews with different group members). In this way, the weaknesses of one method can be compensated by the strengths of the other method (Mays \& Pope, 2000; Streubert \& Carpenter, 2011). At least three sources of information should be used to support each major outcome in triangulation.

\subsection{Research Procedures}

An instructional plan of the instructional design prepared for the subject "Four Arithmetic Operations in Decimals" is given below.

\subsubsection{The Instructional Plan for the Teaching of the Subject "Four Arithmetic Operations in Decimals" Using the Problem-Based Learning Approach in Line With the DDD-E Model}

The detailed version of the instructional design of the micro-level plan is given below. What needs to be done and what has been done at each stage are detailed in this table. In the given plan, the achievements, the teaching approach and the teaching design used are given. Then, the first three steps of the problembased teaching approach, Definition of the Problem, Gathering the Necessary Information and Research Stage, which are discussed in the Decision-making step, which is the first of the sub-steps of the DDD-E model, are mentioned. In the Design and Develop stages, the Transferring and Designing stage of the problem-based learning approach has been adapted, and at this stage, brainstorming and problem solving, testing and evaluation of the produced products are included. The evaluation process, which is the last step but made at all levels, is handled in the Communication step of the problem-based approach. In this stage students discuss what else can be done for improving the design.

\begin{tabular}{|c|c|}
\hline Name of Lesson & Mathematics \\
\hline Level of Class & $6^{\text {th }}$ Grade \\
\hline $\begin{array}{l}\text { The Related } \\
\text { Outcomes }\end{array}$ & $\begin{array}{l}\text { - M.6.1.6.3. They can round the numbers expressed in decimal base up until a } \\
\text { given place. } \\
\text { - M.6.1.6.4. They can perform multiplication using the decimal numbers. } \\
\text { - M.6.1.6.5. They can perform division using the decimal numbers. } \\
\text { - M.6.1.6.6. They can perform multiplications and divisions using the decimal } \\
\text { numbers; } 10,100 \text {, and } 1000 \text { in a shortcut method. }\end{array}$ \\
\hline
\end{tabular}




\begin{tabular}{|c|c|}
\hline & $\begin{array}{l}\text { M.6.1.6.7. They can estimate the results of arithmetic operations performed } \\
\text { using the decimal numbers. } \\
\text { M.6.1.6.8. They can solve problems that require four arithmetic operations } \\
\text { using decimals. }\end{array}$ \\
\hline $\begin{array}{l}\text { Instructional } \\
\text { Approach }\end{array}$ & Problem-Based Learning \\
\hline $\begin{array}{l}\text { Instructional } \\
\text { Design }\end{array}$ & DDD-E Model \\
\hline \multicolumn{2}{|c|}{ The Steps of the DDD-E Model } \\
\hline \multirow[t]{2}{*}{ Decide } & $\begin{array}{l}\text { The Stages of the PBL } \\
\text { Stage 1: Definition of the Problem: A real life problem or a direct engineering } \\
\text { problem is presented. } \\
\text { Stage 2: Gathering the Necessary Information: research what is required to learn } \\
\text { regarding the solution of the problem, what is required for the solution, and gather } \\
\text { information sources. } \\
\text { Stage 3: Research Stage: Students take responsibility of their own learning process } \\
\text { to create or offer proposed solutions for the problem and initiate this process. This } \\
\text { stage includes active processes of creating a hypothesis, an experimental plan for } \\
\text { the hypothesis test, and performing such plan. }\end{array}$ \\
\hline & $\begin{array}{l}\text { The Aim of Learning: The students were asked questions corresponding to the } \\
\text { problem case and were given the opportunity to have an opinion on the problem. } \\
\text { "I am planning to open my own coffee bar. My dream is to have a coffee bar that } \\
\text { has an eye-catching layout. I know that I must calculate all possible expenditures } \\
\text { properly without taking any risk, but I am not skilled in calculation. In other words, } \\
\text { I need an accounting specialist. Additionally, I need to execute a marketing process } \\
\text { by shooting a promotional video. I need some help in this sense. Could you please } \\
\text { make me an offer regarding all these processes?" } \\
\text { Research: Students are given a certain amount of time to decide what types of } \\
\text { materials they plan to use in the coffee bar, and to research in detail rental fees, } \\
\text { material prices, etc. } \\
\text { Brainstorming: Students write in a list detailing what is known and required } \\
\text { regarding the proposed problem by means of brainstorming. At the same time, they } \\
\text { correlate the subject with their previous information. } \\
\text { They brainstorm for the concept to be determined and address the decision process } \\
\text { in detail. }\end{array}$ \\
\hline Design & $\begin{array}{l}\text { Stage 4: Transferring and Designing: In line with the outcomes of the previous } \\
\text { stage, ideas are offered for the solution of the problem through brainstorming, a } \\
\text { design is created, and then tested at this stage. } \\
\text { - Brainstorming } \\
\text { - Creating ideas } \\
\text { - Deciding on the most favorable idea } \\
\text { - Schematizing } \\
\text { - Listing the necessary materials } \\
\text { - Creating a design } \\
\text { - Implementation and Evaluation } \\
\text { Processes included: } \\
\text { Creating A Storyboard: }\end{array}$ \\
\hline
\end{tabular}




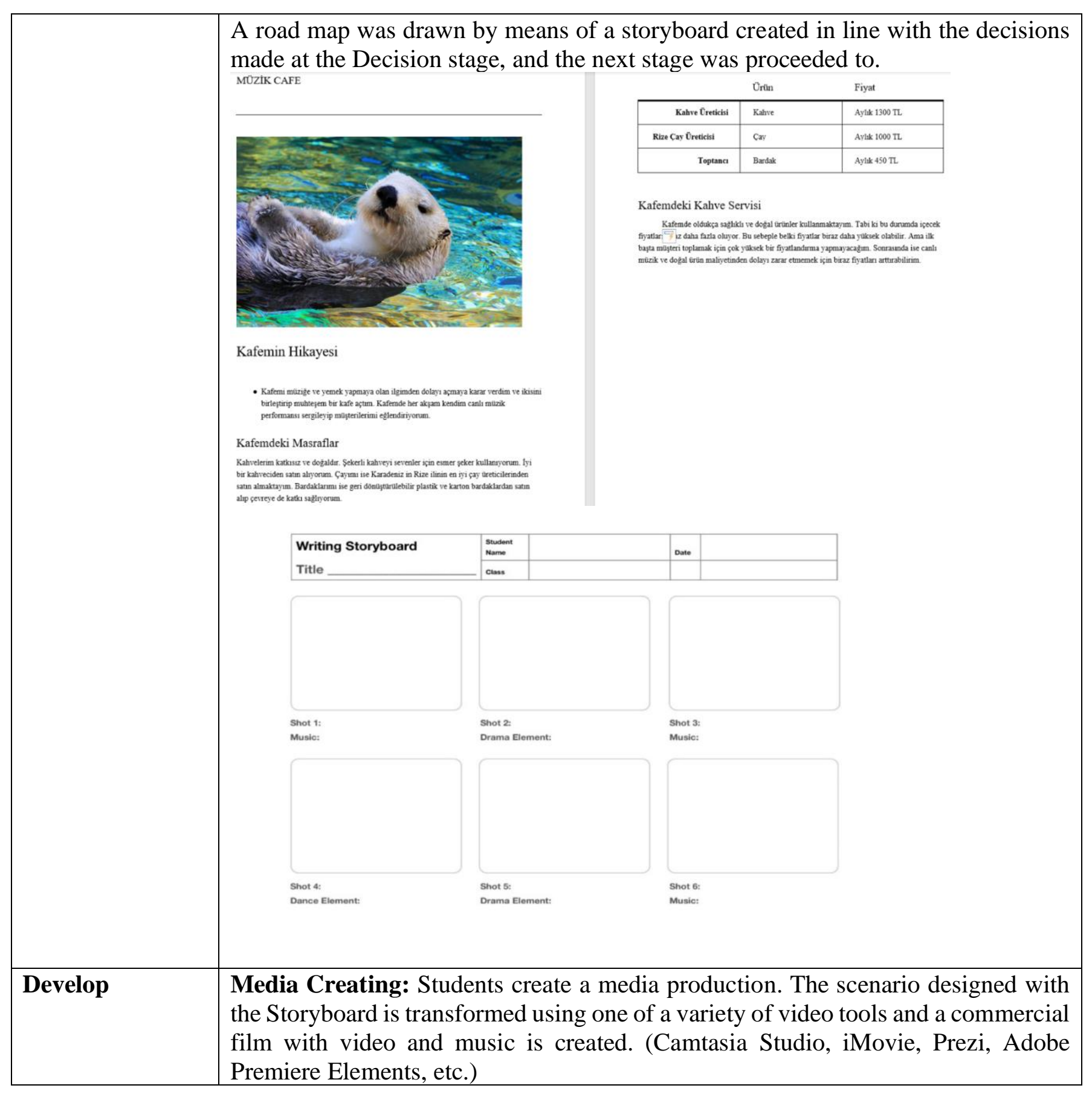




\section{Image and Sound Organizer}

Frame of storyboard:

Image or Sound needed: (Circle one)

Fill in the information below for any images or sounds you found that might work for this frame. Circle the one(s) you choose to use.

\begin{tabular}{|l|l|l|}
\hline Description & Location & Copyright Status \\
\hline & & \\
\hline & & \\
\hline & & \\
\hline & & \\
\hline & & \\
\hline & & \\
\hline
\end{tabular}

Evaluation

Stage 5: Communication: After creating ideas to improve their designs, improving their designs in line with these ideas, and then re-testing their designs, students present and discuss their designs in an instructional environment. They also discuss what else can be done for improving the design.

Continuous Assessment: At every stage of the evaluation process in the instructional design; instructor and intra-group peer evaluations are performed.

\section{Findings and Discussions}

The findings obtained from the data analysis are presented below.

\subsection{Findings Related to Sub-Problem 1}

The attitudes of the students who participated in the research related to activities in which technology and mathematics were integrated together are given in Table 1.

Table 1

Student Attitudes towards Activities Integrating Technology and Mathematics

\begin{tabular}{ll}
\hline Opinions & $\mathrm{f}$ \\
\hline Entertaining & 15 \\
Unnecessary & 3 \\
Boring & 3 \\
\hline
\end{tabular}

It can be seen from the table, 15 of the students said entertaining about the use of technology in the activities, 3 of them said unnecessary and 3 of them said boring. Student attitudes related to solving real life problems using technology are presented in Table 2.

Table 2

Student Attitudes towards Solving Real Life Problems Using Technology

\begin{tabular}{ll}
\hline Opinions & $\mathrm{f}$ \\
\hline Easy to learn & 15 \\
Entertaining & 9 \\
Hard & 1 \\
Boring & 1 \\
\hline
\end{tabular}

According to their responses in the interview questions, students believed that instructional technologies are advantageous in many senses. It can be seen from the table, 15 of the students said easy to learn about 
the solving real life problems by using technology in the activities, 9 of them said entertaining, 1 of them said hard and 1 of them said boring.

For example, (S1) said, "Mathematics is more entertaining when such activities are done. I can better understand the lesson by using technology in the class." This student demonstrated a positive attitude regarding the use of technology in learning.

(S2) said, "It was actually centralized with a system we're not used to, but it was really entertaining." As can be understood from this student's view, it is seen that students learn mathematics by having fun with a new system.

(S5) said, "I actually get bored of writing continuously. I can better learn the subject with such problems. Also, it is more entertaining when we handle real life examples." This student demonstrated a positive attitude regarding the promotive effects of the use of technology in learning.

(S15) said; "I wish we always used technology in all lessons by solving such real-life problems. I can better understand the subject in this way." It can be said that the student with this view has a positive attitude towards mathematics with the use of technology.

(S6) said "The commercial film we prepared at the end of this course was really good. My favorite part of the class was people watching this movie. Because I was proud of it." This student, on the other hand, talked about the pleasure he took in the presentation section at the end of the applied instructional design. This shows that when you give students the opportunity to produce and present the product they produce, positive changes in attitudes can occur.

Finally, (S7) stated that: "We always learned mathematics by writing. This is more favorable and entertaining." This answer showed that the student has a positive attitude for the use of technology, and a higher motivation thanks to such kinds of problem-based activities, and also favorable opinions on the DDD-E model that enables the problem-based learning process to be offered along with technology.

As a result, in the light of the qualitative findings obtained from the opinion forms, it can be said that the students enjoy and have fun while learning mathematics with the designed DDD-E model instructional design. In addition, students who designed something new in the process were supported to develop a positive attitude towards mathematics by being intertwined with technology.

\subsection{Findings Related to Sub-Problem 2}

The scale employed in the study was performed as both a pre-test and post-test to the PBL model application. The data obtained from the pre-test and post-test are given in Table 3 .

Table 3

Arithmetic Mean Points of Students on the Attitude Scale for Technology

\begin{tabular}{lllll}
\hline & $\mathrm{N}$ & $\mathrm{X}$ & $\mathrm{SS}$ & $\mathrm{p}$ \\
\hline Pre-test & 20 & 3.89 & 0.43 & .012 \\
Post-test & 20 & 4.67 & 0.46 &
\end{tabular}

When the mean values of the pre-test and the post-test are examined, the mean values were higher following the application. Moreover, there was a significant difference between the points of the pre-test and the posttest. In light of this data, it can be deduced that the problem-based learning method enhanced positive attitudes on the use of technology in mathematics lesson within the scope of the DDD-E model.

Furthermore, the results of the achievement tests completed by students at the end of the application were examined by specialists. According to the results of these tests, the mean scores of the students were found to be 42 out of 60 points in total. It was seen that 8 questions in average were answered correctly in the achievement test comprised of 12 questions in total. 


\section{Conclusion and Suggestions}

When all of the student opinions are considered, it can be seen that the problem-based learning and DDDE e-learning models within the process of this type of learning contributes to the development of both academic and affective skills of the students, has a positive effect on their attitudes towards mathematics lessons, and enables them to have more improved academic achievements. As Hassan, Habiba, Majeed and Shoaib (2020) suggested in their study, the use of e-learning models contributes to the motivation of students. In this sense, a higher motivation will lead to favorable outcomes regarding academic achievement for mathematic topics which may be difficult to understand.

The literature indicates that as long as it is employed in a proper, well-planned, and programmed manner, the use of technology in mathematics enriches the learning environment, enhances the student motivations, and also contributes to 21 st century skills such as problem solving and critical thinking (Y1ldirım, 2000). In this context, when the instructional necessities of this era are taken into consideration, the use of the DDD-E learning model, which is based on technology, in mathematic learning will improve affective attitudes towards the lesson and academic achievements. Furthermore, the use of problem-based learning will enhance student critical and creative thinking abilities when facing problems that are encountered in daily life and, at the same time, support the development of 21 st century skills.

Today, with the rapid development of technology, novel implementations aimed at distance learning and even the tendency towards technology-based instructional designs such as DDD-E learning are supported (Wahidah et all, 2020). Çetin \& Mirasyedioğulları(2008) suggested in their studay, one of the reasons why technology-assisted problem solving approach is effective in increasing mathematics achievement may be the use of technology in mathematics teaching. Because the visuality offered by technology motivates students, attracts their attention and helps to understand the logic of mathematical concepts. In addition, technology prevents wasting time with transactions and allows students to develop their high-level thinking skills, enabling them to learn better. As a matter of fact, Sheehan and Nillas (2010) determined that technology facilitates students' understanding by visualizing concepts and helps them to establish relationships between different mathematical representations. In addition, many academic studies have confirmed that technology is effective in increasing mathematics achievement. For example, Hannafin (2001) and Ellingon (2003) determined as a result of their research that the use of technology increases students' success in mathematics lessons, their participation in the lesson, their understanding by internalizing the subject and helps them see the relationship of mathematics with the real world. In addition. Furthermore, in the DDD-E model, which requires a student-based approach, students are provided with more practical knowledge about the present technology by using it to help solve real life problems given in the model.

In such times, when the acquisition and processing of knowledge means more, a variety of tools that aid students to access, use, and disseminate knowledge are vital. Revising and updating instructional designs, methods, and programs that are employed within the distance learning process has become vital for improving the skills of the students. Arsovic and Stefanovic (2020) determined that students being educated with the help of e-learning models demonstrated better performance in many senses, had enhanced learning performance, and were provided with a customized method of teaching/learning, and with improved learning processes regarding the cycle of continuous improvement. In this regard, the DDD-E model, which is one of the e-learning models, seems to be a suitable model to use in mathematic learning as well as being an appropriate method to use in the DDD-E model within the scope of problem-based learning.

\section{References}

Alıc1, M. (2018). The Effect of STEM Instruction on Attitude, Career Perception and Career Interest in a Problem-based Learning Environment and Student Opinions (Unpublished master's thesis). Institute of Science Kirikkale University, Kırıkkale. 
Anazifa, R., Djukri, D. (2017). Project- based learning and problem-based learning: are they effective to improve student's thinking skills?. Jurnal Pendidikan IPA Indonesia, 6(2), 346-355. 10.15294/jpii.v6i2.11100

Arsovic, B., Stefanovic, N. (2020). E-learning based on the adaptive learning model: case study in Serbia. Sādhanā, 45, 266. 10.1007/s12046-020-01499-8

Bağc1, N. (2003). New approaches towards students and learning objectives in the learning process. Journal of National Education, 159, 142-148.

Cantürk Günhan, B., Başer, N. (2009). Students', Teachers' and Faculty Members' OpinionsAbout Problem Based Learning, Necatibey Education Faculty Electronic Journal of Science and Mathematics Education, $3(1)$,

134-155. https://dergipark.org.tr/tr/pub/balikesirnef/issue/3368/46498

Cerit, Y. (2008). Students, Teachers and Administrators' Views on Metaphors with Respect to the Concept of Principal. Education and Science, 33(127), 693-712.

Çetin, Y. \& Mirasyedioğlu, Ş. (2019). The effects of the technology supported problem-based learning activities on students' achievement in mathematics. Journal of Computer and Education Research, 7(13), 13-34. https://doi.org/10.18009/jcer.494907

Dağhan G., Kalaycı E., Seferoğlu S. S. (2011). The examination of technology policies in national education councils. Academic Informatics, 2(4), Inonu University, Malatya.

Delisle, R. (1997). How to use problem-based learning in the classroom. https://www.ascd.org/books/howto-use-problem-based-learning-in-the-classroom.

Divarc1, Ö, Saltan, F. (2017). The Effects of the Multimedia Supported Problem Based Learning on Academic Success and Attitude in Science Education. Journal of Ahi Evran University Kirsehir Education Faculty, 18(3), 1-23. https://dergipark.org.tr/tr/pub/kefad/issue/59420/853347

Ellington, A. J. (2003). A meta-analysis of the effects of calculators on students' achievement and attitude levels in precollege mathematics classes. Journal for Research in Mathematics Education, 34(5), 433-463.

Ersoy, E, Başer, N. (2011). The Effect on Retention of Applied Scenarios in the Problem-Based Learning Method. Journal of Uludag University Faculty of Education, 24(2), 355-366. https://dergipark.org.tr/tr/pub/uefad/issue/16694/173522

Göktaş Y., Yıldırım Z., Yıldırım S. (2008), Status of ICT in schools of teacher education: deans' views, Education and Science, 33(149), 30-50.

Hannafin, R. D., Burruss, J. D. ve Little, C. (2001). Learning with dynamic geometry programs: Perspectives of teachers and learners. Journal of Educational Research, 94(3), 132-44.

Hassan, M., Habiba, U., Majeed, F., Shoaib, M. (2019). Adaptive gamification in e-learning based on students' learning styles. Interactive Learning Environments, 29(4), 545-565. 10.1080/10494820.2019.1588745.

Hmelo-Silver, C. E. (2004), Problem-based learning: what and how do students learn?. Educational Psychology Review, 16, 235-266. 10.1023/B:EDPR.0000034022.16470.f3 .

İpek, İ., Sözcü, Ö. \& Ziatdinov, R. (2013, Ocak). Integrated E-Learning Design Model and Rapid Instructional Design Strategies. XV. Academic Informatics Conference, Antalya.

Ivers, K. S., Ann E. B. (2002). Multimedia projects in education designing, producing, and assessing. Retrieved

from 
https://www.academia.edu/download/35952048/_Karen_S._Ivers_Ann_E._Barron_Multimedi ProjectBookFi.org.pdf

Ellis-Barrett, L. (2007), Multimedia projects in education: designing, producing and assessing third edition, Library Review, 56(3), 264-265. 10.1108/00242530710736145.

Karataş, Z. (2017). Paradigm transformation in social sciences research: rise of qualitative approach. Turkish Journal of Social Work Research 1(1).

Kaya, Z. (2002). Distance Education. Retrieved from http://www.jret.org/FileUpload/ds217232/File/uzaktanegitim.pdf

K1lıç, İ., Moralar, A. (2015). The effect of problem-based learning approach on academic success and motivation in science education. Pegem Journal of Education and Training, 5(5). 10.14527/pegegog.2015.034

Mays, N., \& Pope, C. (2000). Qualitative research in health care, assessing quality in qualitative research. BMJ, 320, 50-52

Mazman, S. G., Usluel, Y. K. (2011). Ict integration into learning-teachingprocess: models and indicators. Educational Technology Theory and Practice, 1(1), 62-79. https://dergipark.org.tr/tr/pub/etku/issue/6274/84241

Muhammad N., Herminarto S., Moh F., Rabiman R. (2019). Problem-based learning (pbl) in industry 4.0: improving learning quality through character-based literacy learning and life career skill (ll-lcs). Universal Journal of Educational Research, 7(11), 2487-2494. 10.13189/ujer.2019.071128.

Nugraha, F.F. (2017). Interactive multimedia use of games model on ips school study list. Education Program of Elementary School of Universitas Kuningan Journal of Elemantary Education, 1(1), 17. 10.22460/pej.v1i1.421.

Sheehan, M. \& Nillas, A.L. (2010). Technology integration in secondary mathematics classrooms: Effect on students' understanding. Journal of Technology Integration in the Classroom, 2(3), 67-83.

Stake, R. R. (2005). Case studies. In N. K. Denzin \& Y. S. Lincoln (Eds.), The SAGE handbook of qualitative research (Third edition). London: Sage.

Streubert, H. J., \& Carpenter, D. R. (2011). Qualitative research in nursing. (5th ed.). Philadelphia: Lippincott Williams ve Wilkins.

Tutak, T. (2020). The effect of problem-based learning approach on student achievement and attitude in teaching linear equations and inequalities. Electronic Journal of Education Sciences, 9(18), 97-108.

Wahidah N. I., Ibrahim N, Muslim S. (2019). E-module : Design a learning material with rowntree and hannafin model for higher education. International Journal of Scientific \& Technology Research, 8(12), 3373-3376.

Uygun, N., Iş1k Tertemiz, N. (2014). Effects of problem-based learning on student attitudes, achievement and retention of learning in math course. Education and Science, 39(174). 10.15390/EB.2014.1975

Yin, R. (1984). Case study research: design and methods (3rd edition). California: Sage.

Y1ldırım, S. (2000). An indispensable educational tool. Information Week Türkiye, 111, 45-46.

Yurdugül, H., Aşkar, P. (2008). An investigation of the factorial structures of pupils' attitude towards technology (patt): A Turkish sample. Elementary Education Online, 7(2), 288-309. 


\section{Appendix}

\section{Appendix-1}

Aşağıdaki toplama ve çıkarma işlemlerini yapınız. a) $0,4+0,123=$

b) $1,2+13+0,004=$

c) $23,12+1,238-0,32=$

d) $111,13+0,2+13=$

Aşağıdaki çarpma işlemlerini yapınız.

a) $0,4 \times 0,123=$

b) $1,2 \times 13=$

c) $1,23 \times 0,32=$

d) $0,2+1,03=$

Aşağıdaki bölme işlemlerini yapınız.

a) $0,4: 0,1=$

b) $1,2: 0,06=$

c) $1,23: 12,3=$

d) $0,2: 1,03=$ 